\title{
PENGEMBANGAN KURIKULUM PENDIDIKAN DINIYAH FORMAL (PDF) DI PESANTREN ULYA ZAINUL HASAN PROBOLINGGO
}

\author{
CURRICULUM DEVELOPMENT OF FORMAL DINIYAH EDUCATION: \\ CASE STUDY PDF ULYA ZAINUL HASAN PROBOLINGGO
}

\author{
Saridudin \\ Puslitbang Pendidikan Agama dan Keagamaan, Badan Litbang dan Diklat, Kementerian Agama RI \\ email: dudinsaridudin@gmail.com
}

Naskah Diterima: 20 November 2019; Direvisi: 17 Maret 2020; Disetujui: 25 April 2020

\begin{abstract}
This study aims to determine the curriculum development model such as what was developed by PDF Ulya Zainul Hasan Genggong, East Java Province. This research is qualitative research with a case study approach. Data collection is done by observation, interview, and document search. This research resulted in the finding that PDF Ulya Zainul Hasan succeeded in developing his curriculum not only in mastering the yellow book and religious experts (mutafaqquh fiddin) but oriented towards the development of life skills. Some life skills activities developed include computer engineering, jenazah management training, cooperatives, pencak silat, marawis and hadrah art. Besides, several extracurricular activities were also developed, including the bahsul massail group, Arabic language guidance, khitobah guidance, and Hajj ritual training. This success is supported by several factors such as the context of the PDF policy, the input of santri and ustad, the learning process and the PDF output that can give color to the social life of pesantren and the community. This research suggests that related educational institutions continue to socialize PDF on a massive scale through various channels, including the Ministry of Religious Affairs, the Ministry of Education, Islamic boarding schools, and the general public, so that PDF gets wider recognition and creates a positive brand image about Formal Diniyah Education.
\end{abstract}

Keywords: Curriculum development; Formal diniyah education; Life skills

\begin{abstract}
Abstrak
Penelitian ini bertujuan untuk mengetahui model pengembangan kurikulum seperti apa yang dikembangkan Pendidikan Diniyah Formal (PDF) Ulya Zainul Hasan Genggong Provinsi Jawa Timur. Penelitian ini merupakan penelitian kualitatif dengan pendekatan studi kasus. Pengumpulan data dilakukan dengan observasi, wawancara dan penelusuran dokumen. Penelitian ini menghasilkan temuan bahwa PDF Ulya Zainul Hasan berhasil mengembangkan kurikulumnya tidak hanya dalam penguasaan kitab kuning dan ahli agama (mutafaqquh fiddin) tapi diorientasikan pada pengembangan life skills. Beberapa kegiatan life skills yang dikembangkan di antaranya teknik komputer, training pengurusan jenazah, koperasi, pencak silat, marawis dan seni hadrah. Selain itu juga dikembangkan beberapa kegiatan ekstrakurikuler antara lain kelompok bahsul masail, bimbingan bahasa arab, bimbingan khitobah, dan pelatihan manasik haji. Keberhasilan ini didukung beberapa faktor seperti konteks kebijakan PDF, input santri dan ustadz, proses pembelajaran dan output PDF yang mampu memberikan warna bagi kehidupan sosial pesantren dan masyarakat. Penelitian ini menyarankan agar lembaga pendidikan terkait terus mensosialisasikan PDF secara masif melalui berbagai jalur baik Kementerian Agama, Kementerian Pendidikan, pondok pesantren, maupun masyarakat umum, sehingga PDF mendapat rekognisi yang lebih luas dan tercipta brand image yang positif tentang Pendidikan Diniyah Formal.
\end{abstract}

Kata Kunci: Life skills; Pendidikan diniyah formal; Pengembangan kurikulum 


\section{PENDAHULUAN}

Pendidikan Diniyah Formal (PDF) merupakan jenis pendidikan yang masih baru dan belum banyak dikenal masyarakat. Pendidikan jenis ini terdengar asing bagi sebagian masyarakat, bahkan bagi sebagian pegawai Kementerian Agama, khususnya di luar Direktorat Pendidikan Diniyah dan Pondok Pesantren, istilah tersebut belum tersosialisasi secara luas, baik di tingkat kabupaten, provinsi maupun di tingkat pusat sendiri.

Pada wilayah praktis, di tingkat lokal kabupaten dan provinsi, Kantor Kementerian Agama setempat tidak diberi kewenangan secara penuh dalam mengelola penyelenggaraannya. Kewenangan tersebut secara sentralistik berada di bawah pemerintah pusat dalam hal ini adalah Direktorat Pendidikan Diniyah dan Pondok Pesantren. Kantor Kementerian Agama Kabupaten hanya sebagai pembina dan pendamping khususnya dalam izin pendirian, selebihnya kebijakan menjadi kewenangan pemerintah pusat seperti dalam penyelenggaraan Ujian Nasional (imtihan wathani), distribusi dan pembuatan soal, kepanitiaan, pengawasan dan administrasi lainnya. Sehingga dengan hal tersebut Kantor Kementerian Agama Kabupaten kadang tidak mengetahui perkembangan yang terjadi, karena sosialisasi kebijakan biasanya secara langsung disampaikan ke PDF yang bersangkutan.

Dalam kenyataan, penyelenggaraan PDF mengalami banyak problematika yang dihadapi. Berdasarkan pengamatan stakeholder, terdapat kesiapan dan penyelenggaraan PDF di pesantren yang kurang optimal, antara lain: (1) dari sisi input, kurikulum PDF masih tumpang tindih dengan kurikulum Ma'had Aly, ustaz kurang memenuhi standar kualifikasi akademik, sarana prasarana dan pembiayaan PDF kurang memadai; (2) dari sisi proses, pengelolaan pembelajaran masih relatif konvensional dan evaluasi pembelajaran kurang sistematis (Dudin, 2019).

Idealnya, perbaikan terhadap sistem kelembagaan itu diarahkan pada kekuatan lembaga pendidikan pesantren sebagai agen perubahan (agent of change), dalam artian pesantren harus membuka diri terhadap tuntutan perubahan yang diinginkan oleh masyarakat (Suyanto, 2016). Pengembangan kurikulum pendidikan pesantren yang terus menerus menyangkut seluruh komponen merupakan sesuatu yang mutlak untuk dilakukan agar ia tidak kehilangan relevansi (Busthomi, 2019)

Kata kuncinya adalah bagaimana PDF dan pesantren mengembangkan kurikulum yang menarik yang diminati masyarakat, karena kurikulum merupakan sebuah wadah yang akan menentukan arah pendidikan (Mualim, Anshori, \& Ali, 2019). Sebagai salah satu komponen penting, kurikulum dituntut untuk dapat mengikuti perkembangan dan tuntutan zaman. Hal ini menjadi salah satu faktor dalam pengembangan kurikulum yang kiranya perlu dilakukan untuk ketercapaian kompetensi peserta didik untuk dapat tetap survive di era milenial (Wibisono, 2019).

Kurikulum tidak hanya berisikan pengetahuan ilmiah berupa daftar mata pelajaran semata tanpa memperhatikan pengalaman belajar yang bermakna, justru sebaliknya bahwa mata pelajaran itu hanyalah merupakan kemasan pengalaman belajar yang bermakna sangat dibutuhkan oleh anak didik dalam kehidupannya (Taufik, 2019). Kurikulum dapat diibaratkan sebagai sebuah kendaraan umum yang membawa penumpangnya ke tempat tujuan (Bahri, 2018). Kurikulum adalah alat atau instrumen untuk mendidik peserta didik untuk mengembangkan potensi jismiyah dan ruhiyahnya agar peserta didik mampu menuju kepada Tuhannya (Salim, 2019).

Sebagai lembaga pendidikan yang masih baru, PDF belum mendapatkan core yang lebih jelas tentang arah, tujuan dan orientasi Pendidikannya. Kenyataan inilah yang kemudian dijawab oleh PDF Ulya Zainul Hasan dengan mengembangkan kurikulum yang tidak hanya menjadikan santri sebagai ahli agama (mutaqquh fiddin) dengan kompetensi penguasaan kitab kuning, tetapi pada pengembangan life-skill santri PDF di pesantren. Keberhasilan PDF Ulya Zainul Hasan ini didukung oleh beberapa faktor antara lain konteks, input, proses maupun produk, sehingga hal tersebut berdampak pada kehidupan sosial budaya pesantren dan masyarakat. 
Tulisan ini bertujuan untuk melengkapi kekurangan studi tentang penyelenggaraan PDF di pesantren dengan menjawab tiga pertanyaan penting: (1) Bagaimana praktik pengembangan kurikulum PDF Ulya Zainul Hasan Genggong Probolinggo dilaksanakan?, (2) Faktor apa yang menjadi penentu keberhasilan pengembangan kurikulum PDF Ulya Zainul Hasan Genggong Probolinggo?, (3) Bagaimana pengembangan kurikulum PDF berpengaruh terhadap konteks sosial budaya pesantren dan masyarakat?

Argumen yang menjadi dasar tulisan ini adalah bahwa pengembangan kurikulum perlu dilakukan di satuan pendidikan PDF. Santri PDF dituntut tidak hanya memiliki kompetensi dalam bidang kitab kuning dan ahli agama (mutafaqquh fiddin), tapi dalam rangka menghadapi kehidupan masyarakat yang terus berubah, mereka dituntut untuk punya kompetensi dalam lifes-skill atau keterampilanketerampilan yang lain. Keberhasilan pengembangan kurikulum PDF akan sangat dipengaruhi oleh beberapa faktor di antaranya adalah konteks, input, proses maupun produk atau out-put. Santri PDF dituntut untuk punya kompetensi dalam dua bidang sekaligus baik akademik maupun non-akademik. Sehingga keberadaan santri bisa mewarnai dinamika kehidupan sosial pesantren dan masyarakat luas yang begitu kompleks.

\section{KAJIAN PUSTAKA}

Pengertian kurikulum seperti yang tertera dalam Undang-undang No. 20 Tahun 2003 tentang Sistem Pendidikan Nasional ialah "seperangkat rencana dan pengaturan mengenai tujuan, isi dan bahan pelajaran serta cara yang digunakan sebagai pedoman penyelenggaraan kegiatan pembelajaran untuk mencapai tujuan pendidikan tertentu". Istilah kurikulum digunakan dalam dunia pendidikan. Para ahli pendidikan memiliki penafsiran yang berbeda tentang kurikulum. Namun demikian, dalam penafsiran yang berbeda itu, ada juga kesamaannya. Kesamaan itu adalah bahwa kurikulum berhubungan erat dengan usaha mengembangkan siswa sesuai dengan tujuan yang ingin dicapai (Sanjaya, 2008, 3). Dari penelusuran konsep, pada dasarnya kurikulum memiliki tiga dimensi pengertian, yaitu kurikulum sebagai mata pelajaran, kurikulum sebagai pengalaman belajar dan kurikulum sebagai perencanaan program pembelajaran.

Konsep kurikulum sebagai mata pelajaran biasanya erat kaitannya dengan usaha untuk memperoleh ijazah. Ijazah sendiri pada dasarnya menggambarkan kemampuan. Artinya apabila siswa telah berhasil mendapatkan ijazah berarti ia telah menguasai pelajaran sesuai dengan kurikulum yang berlaku. Kurikulum sebagai pengalaman adalah seluruh kegiatan yang dilakukan siswa baik di dalam maupun di luar sekolah asal kegiatan tersebut berada di bawah tanggung jawab guru (sekolah). Yang dimaksud dengan kegiatan itu tidak terbatas pada kegiatan intra ataupun ekstra kurikuler. Apapun yang dilakukan siswa asal saja ada di bawah tanggung jawab dan bimbingan guru, itu adalah kurikulum.

Pada saat sekarang istilah kurikulum memiliki empat dimensi pengertian, di mana satu dimensi dengan dimensi lainnya saling berhubungan. Keempat dimensi kurikulum tersebut yaitu: (1) kurikulum sebagai suatu ide/gagasan, (2) kurikulum sebagai suatu rencana tertulis yang sebenarnya merupakan perwujudan dari kurikulum sebagai suatu ide, (3) kurikulum sebagai suatu kegiatan yang sering pula disebut dengan istilah kurikulum sebagai suatu realita atau implementasi kurikulum. Secara teoretis dimensi kurikulum ini adalah pelaksanaan dari kurikulum sebagai suatu rencana tertulis. (4) kurikulum sebagai suatu hasil yang merupakan konsekuensi dari kurikulum sebagai suatu kegiatan (Hasan, 2009, 121).

Pengertian kurikulum sebagai dimensi yang berkaitan dengan ide pada dasarnya mengandung makna bahwa kurikulum itu adalah sekumpulan ide yang akan dijadikan pedoman dalam pengembangan kurikulum selanjutnya. Pengertian kurikulum dikaitkan dengan dimensi rencana adalah sebagai seperangkat rencana dan cara mengadministrasikan tujuan, isi, dan bahan pelajaran serta cara yang digunakan sebagai pedoman penyelenggaraan kegiatan pembelajaran untuk mencapai tujuan Pendidikan tertentu. Pengertian kurikulum sebagai dimensi aktivitas memandang kurikulum merupakan segala aktivitas dari 
guru dan siswa dalam proses pembelajaran di sekolah. Definisi kurikulum sebagai dimensi hasil memandang kurikulum itu sangat memperhatikan hasil yang akan dicapai oleh siswa agar sesuai dengan apa yang telah direncanakan dan yang menjadi tujuan dari kurikulum tersebut.

Pengembangan kurikulum adalah proses perencanaan dan penyusunan kurikulum oleh pengembang kurikulum (curriculum developer) dan kegiatan yang dilakukan agar kurikulum yang dihasilkan dapat menjadi bahan ajar dan acuan yang digunakan untuk mencapai tujuan pendidikan nasional. Pengembangan kurikulum menunjuk pada kegiatan menghasilkan kurikulum. Kegiatan pengembangan, terdiri dari kegiatan penyusunan, pelaksanaan, penilaian, dan penyempurnaan sehingga menghasilkan sesuatu.

Istilah pengembangan Kurikulum (curriculum development) menurut Oliva (2012), memiliki makna yang lebih komprehensif yaitu mencakup perencanaan (planning), pelaksanaan (implementation), dan evaluasi (evaluation). Tahap perencanaan kurikulum merupakan proses awal bagi para pengembang kurikulum untuk mengambil keputusan dan tindakan sehingga melahirkan suatu desain kurikulum yang mengandung empat komponen kurikulum utama, yaitu: tujuan, isi/bahan, aktivitas, belajar-mengajar dan evaluasi. Dan implementasi kurikulum merupakan tahap penjabaran desain kurikulum ke dalam tindakan nyata.

Sedangkan tahap evaluasi kurikulum merupakan tahap akhir dari proses pengembangan kurikulum di mana hasil-hasil penerapan kurikulum dinilai efektivitas dan efisiensinya, baik yang berhubungan dengan produk pendidikannya maupun kurikulum itu sendiri. Pengembangan kurikulum pada dasarnya memang dibutuhkan manakala kurikulum yang berlaku (current curriculum) dipandang sudah tidak efektif atau tidak relevan lagi dengan tuntutan perkembangan zaman (Hidayat, 2020).

Pendidikan Diniyah Formal (PDF) menurut PMA No 13 tahun 2014 tentang Pendidikan Keagamaan Islam dan Keputusan Dirjen Pendis No 5839 tahun 2014 tentang
Pedoman Pendirian Pendidikan Diniyah Formal adalah lembaga pendidikan keagamaan Islam yang diselenggarakan oleh dan berada di dalam pesantren secara terstruktur dan berjenjang pada jalur pendidikan formal. Jenjang pendidikan diniyah formal terdiri atas pendidikan dasar, pendidikan menengah dan pendidikan tinggi. Pendidikan diniyah formal jenjang pendidikan dasar terdiri atas pendidikan diniyah formal ula dan pendidikan diniyah formal wustha. Pendidikan diniyah formal jenjang pendidikan menengah berbentuk pendidikan diniyah formal ulya. Sedangkan Pendidikan diniyah formal jenjang pendidikan tinggi berbentuk Ma'had Aly.

Pendidikan Diniyah Formal Ula merupakan pendidikan yang sederajat dan memiliki kewenangan yang sama dengan Madrasah Ibtidaiyah/Sekolah Dasar. Pendidikan diniyah formal wustha merupakan pendidikan yang sederajat dan memiliki kewenangan yang sama dengan Madrasah Tsanawiyah/Sekolah Menengah Pertama. Pendidikan diniyah formal ulya merupakan pendidikan yang sederajat dan memiliki kewenangan yang sama dengan Madrasah Aliyah/Sekolah Menengah Atas/Sekolah Menengah Kejuruan. Pendidikan diniyah formal ula terdiri atas 6 (enam) tingkat. Pendidikan diniyah formal wustha terdiri atas 3 (tiga) tingkat. Pendidikan diniyah formal ulya terdiri atas 3 (tiga) tingkat.

Kurikulum pendidikan diniyah formal terdiri atas kurikulum pendidikan keagamaan Islam dan kurikulum pendidikan umum. Kurikulum pendidikan keagamaan Islam sebagaimana dimaksud dalam Pasal 26 pada satuan pendidikan diniyah formal ulya paling sedikit memuat 14 mata pelajaran di antaranya Al-Qur'an, Tafsir-Ilmu Tafsir, Hadist-Ilmu Hadits, Tauhid, Fiqh-Ushul Fiqh, AkhlaqTasawuf, Tarikh, Bahasa Arab, Nahwu-Sharf, Balaghah, Ilmu Kalam, Ilmu Arudh, Ilmu Mantiq, dan Ilmu Falak.

Kurikulum pendidikan umum pada satuan pendidikan diniyah formal ulya paling sedikit memuat pendidikan kewarganegaraan, bahasa Indonesia, matematika, ilmu pengetahuan alam dan seni budaya. Proses pembelajaran pada pendidikan diniyah formal 
dilaksanakan dengan memperhatikan aspek ketercapaian kompetensi, sumber dan sarana belajar, konteks lingkungan, dan psikologi peserta didik. Pengelolaan satuan pendidikan diniyah formal dilakukan dengan menerapkan manajemen dengan prinsip keadilan, kemandirian, kemitraan dan partisipasi, nirlaba, efisiensi, efektivitas, dan akuntabilitas.

Studi tentang penyelenggaraan PDF di pesantren masih jarang dilakukan, beberapa penelitian yang dilakukan di antaranya A.M. Wibowo,dkk. (2018) dengan judul Kaderisasi Ulama Toleran melalui Pendidikan Diniyah Formal pada Pesantren Salafiyah di Jawa Tengah dan Jawa Timur. Penelitian dilakukan terhadap 6 pesantren dan PDF yaitu Pondok Pesantren dan PDF Walindo Manbaul Falah Pekalongan, Pondok Pesantren dan PDF AlMubarok Manggisan Wonosobo, Pondok Pesantren dan PDF Al-Fitroh Surabaya, Pondok Pesantren dan PDF Apik Kaliwungu Kendal, Pondok Pesantren dan PDF Cokrokertopati Takeran Magetan dan Pondok Pesantren dan PDF Al-Mahrusyiyah Lirboyo Kediri.

Penelitian menyimpulkan (1) kaderisasi ulama toleran melalui pesantren Pendidikan Diniyah Formal dilakukan dengan cara memproses input santri yang ada dalam pesantren PDF dengan kurikulum dan sumber daya asatid, (2) bentuk kaderisasi ulama toleran melalui PDF pada tingkat Ulya dilakukan melalui kurikulum faktual dan hidden kurikulum yaitu budaya-budaya keseharian di pesantren PDF, (3) faktor-faktor yang mempengaruhi keberlangsungan pendidikan di pesantren PDF dalam membentuk kader ulama toleran adalah kekuatan berupa keteladanan dan karismatik kiai pengasuh pondok pesantren, lokasi PDF yang strategis, dan asatid yang memiliki kompetensi pada bidang yang diajarkannya.

Penelitian yang lain dilakukan oleh Ratna Dewi dan Jetro Limbong (2018) yang memfokuskan bahasan pada Manajemen Pendidikan Diniyah Formal. Penelitian dilakukan terhadap Pendidikan Diniyah Formal Al-Jawahir dan Pendidikan Diniyah Formal Al-Masturiyah. Pendidikan Diniyah Formal Al-Jawahir berada dibawah yayasan pendidikan Panca Sari berlokasi di Soreang
Kabupaten Bandung, sedangkan Pendidikan Diniyah Formal Al-Masturiyah berada di bawah yayasan Al-Masturiyah berlokasi di Cisaat Sukabumi. Pengelolaan lembaga Pendidikan Diniyah Formal dilakukan terpisah dari pengelolaan pesantren dan dipimpin oleh seorang kepala. Pesantren yang merasa memenuhi syarat untuk menyelenggarakan Pendidikan Diniyah Formal, perlu melakukan pengajuan kepada Kementerian Agama terkait dengan operasionalnya. Kepala PDF selanjutnya menjalin koordinasi dengan kiai sebagai pimpinan pesantren terkait pembelajaran yang akan disampaikan kepada santri. Aktivitas belajar santri yang padat, memicu kekhawatiran munculnya berbagai kendala dalam mengikuti proses belajar. Untuk itu diperlukan upaya untuk mensinergikan kurikulum. Selain itu, sinergitas kurikulum juga akan berdampak pada pengelolaan lembaga. Efisiensi jam belajar siswa dapat mengurangi jumlah tenaga pendidik, yang berakibat positif terhadap pengelolaan keuangan lembaga.

Dalam pandangan yang lain penelitian Suyanto (2007) melakukan penelitian di lima pesantren di Kota Bengkulu yaitu Pondok Pesantren Hidayatul Qomariyah, Pondok Pesantren Hidayatul Mubtadi'in, Pondok Pesantren Pancasila, Pondok Pesantren Darussalam dan Pondok Pesantren Salafiyah Sentot Alibasya. Manajemen penjenjangan PDF pada pesantren di Kota Bengkulu belum memenuhi persyaratan sebagai penyelenggara Pendidikan Diniyah Formal (PDF). Pondok Pesantren Hidayatul Qomariyah dan Hidayatul Mubtadiin adalah 2 (dua) pesantren yang telah melakukan persiapan. Adapun alasan pondok pesantren di Kota Bengkulu memilih menyelenggarakan pendidikan formal adalah untuk merespons keinginan masyarakat agar putra-putrinya setelah tamat dari pesantren tersebut memiliki ijazah. Jika pondok pesantren tidak menyelenggarakan pendidikan formal maka sangat sedikit santri yang mau belajar di pondok pesantren.

Studi lainnya dilakukan oleh Suroso (2017) mengenai Manajemen Pembelajaran Pendidikan Diniyah Formal Tingkat Wustho Pondok Pesantren Assalafi Al Fitrah Surabaya. Hasil penelitian menunjukkan secara umum 
manajemen pembelajaran di PDF Ponpes Assalafi Al Fithrah Surabaya sudah terlaksana mulai dari perencanaan pembelajaran di mana ustadz/ustadzah membuat perencanaan pembelajaran khususnya terkait penguasaan materi, alokasi dan tujuan pembelajaran, meskipun perencanaan ini belum tertulis secara sistematis. Keadaan ini dikarenakan baru adanya panduan perencanaan pembelajaran yang ditetapkan secara nasional juga kesibukan ustadz/ustadzah sehingga rencana pembelajaran belum tersusun secara terperinci. Selain itu, juga karena mata pelajaran umum adalah hal yang baru, sehingga indikator pencapaian tujuannya adalah sesuai dengan kurikulum yang telah ditetapkan.

Studi yang terbaru dilakukan oleh Syukron (2020) dengan judul Kurikulum Pendidikan Diniyah Formal Dalam Pondok Pesantren. Syukron melakukan penelitian di PDF pesantren APIK dan Walindo. Hasil kajian menunjukkan bahwa secara umum pelaksanaan kurikulum PDF yang dilaksanakan di pondok pesantren APIK dan Walindo sudah sesuai dengan aturan dasar PDF yang telah ditetapkan oleh pemerintah mulai dari tujuan, materi dan sumber belajar, alokasi waktu, serta sistem penilaian. Meskipun demikian, pesantren tersebut masih tetap mempertahankan kekhasan pesantren yang meliputi muatan lokal, pengelolaan kelas, serta strategi pembelajaran yang digunakan seperti bandongan dan sorogan.

Selain beberapa studi yang dijelaskan di atas, penelitian lainnya antara lain Syamsudin (2018) model pembelajaran berdasarkan masalah yang dikembangkan di PDF Wustha Al-Fitrah Surabaya, Wahid (2016) Pendidikan Diniyah Formal sebagai wajah baru pendidikan pesantren untuk kaderisasi ulama, Sahri dan Hidayah (2020) telaah atas single sex classroom di PDF Ulya pesantren Al-Fithrah Surabaya, Dwi Istiyani (2017) tantangan dan eksistensi madrasah diniyah sebagai entitas kelembagaan pendidikan keagamaan Islam di Indonesia.

Dari beberapa penelitian di atas belum ada penelitian yang secara khusus membahas bagaimana pengembangan kurikulum dilakukan oleh satuan PDF yang mengembangkan pada pendidikan kecakapan hidup (life skilss). Mengkaji pengembangan kurikulum PDF dengan penekanan pada pendidikan life skills yang di dukung konteks, input, proses dan produk atau out-put yang berdampak pada kehidupan sosial budaya pesantren dan masyarakat menjadi penting untuk dijelaskan. Pada posisi inilah penelitian ini dikembangkan.

\section{METODOLOGI}

Penelitian ini menggunakan pendekatan kualitatif. Penelitian kualitatif digunakan karena permasalahan sangat dinamis, bisa berkembang, kondisi objek yang alamiah, belum terlalu jelas, holistik, kompleks, dan penuh makna, dengan tempat penelitian satuan Pendidikan Diniyah Formal (PDF) Ulya Zainul Hasan Genggong Probolinggo Jawa Timur. Instrumen utama pada penelitian ini adalah peneliti sendiri (human instrument).

Sumber data pada tahap awal memasuki lapangan dipilih orang yang memiliki power dan otoritas pada situasi sosial atau objek yang diteliti. Dalam penelitian ini, peneliti menggunakan teknik pengumpulan data yang meliputi observasi, wawancara, dokumentasi dan studi pustaka. Observasi dilakukan untuk mengamati secara langsung kondisi proses belajar mengajar di PDF Ulya Zainul Hasan terutama yang berkaitan dengan pembelajaran life skills. Wawancara dilakukan terhadap informan kunci seperti kepala PDF, pengasuh pesantren, kepala TU, guru/ustadz PDF dan santri PDF Ulya Zainul Hasan. Hasil wawancara dicatat melalui catatan tertulis atau melalui perekaman video/audio tape, pengambilan foto dan film. Studi dokumentasi dilakukan untuk menggali data-data pendukung yang diperoleh dari dokumendokumen terkait untuk kemudian dideskripsikan menjadi kalimat naratif yang menunjang data-data yang lain.

Untuk memperoleh data tambahan tentang penyelenggaraan PDF Ulya Zainul Hasan, peneliti mencari dan mendokumentasikan berbagai data dari sumber lain guna memperkaya data, baik melalui buku, foto, artikel, surat kabar, data statistik, dan lain sebagainya. Karena dalam penelitian ini menggunakan metode observasi, wawancara, dan dokumentasi, maka intrumen yang 
dibutuhkan antara lain yaitu pedoman observasi, pedoman wawancara, dan daftar isian tentang santri, ustad, TU dan Kepala PDF. Dalam melaksanakan telaah dokumen, peneliti menyelidiki benda-benda tertulis seperti buku-buku, majalah, dokumen, peraturan-peraturan, notulen rapat, catatan harian dan sebagainya. Adapun telaah dokumen dilakukan untuk menyelidiki bendabenda tertulis yang berkaitan dengan penelitian ini. Telaah dokumen juga dilakukan pada buku-buku yang ada kaitan dengan penelitian.

Teknik analisa data dilakukan bersamaan dengan pengumpulan data, ketika memasuki lapangan dengan grand tour dan mini tour question, yaitu dengan analisis domain. Tahapan selanjutnya adalah menentukan fokus, teknik pengumpulan datanya dengan mini tour question, analisis data dilakukan dengan analisis taksonomi. Selanjutnya pada tahap seleksi, pertanyaan yang digunakan adalah pertanyaan struktural, analisis data dengan analisis komponensial, dan selanjutnya adalah analisis tema. Jadi analisis dilakukan secara interaktif melalui empat komponen di mana keempat komponen tersebut merupakan proses siklus dalam penelitian ini. Keempat komponen tersebut ialah reduksi data, penyajian data, penafsiran dan penyimpulan data.

\section{HASIL DAN PEMBAHASAN}

\section{Pengembangan Kurikulum PDF Ulya Zainul Hasan}

Pesantren Zainul Hasan pada awal berdirinya dikenal dengan Pondok Pesantren Genggong, didirikan oleh K.H. Zainul Abidin, seorang ulama keturunan Maghribi dan alumnus pesantren Sidoresmo Surabaya pada tahun $1839 \mathrm{M} / 1250 \mathrm{H}$, terletak di desa Karangbong Kecamatan Pajarakan Kabupaten Probolinggo Jawa Timur. Nama Pondok Genggong diabadikan sejak kepemimpinan K.H. Zainul Abidin sampai dengan kepemimpinan K.H. Moh. Hasan dari tahun 1839 sampai dengan 1952M (113 tahun). Pada masa kepemimpinan K.H. Hasan Saifourridzall nama Pesantren Genggong diubah dengan nama Asrama Pelajar Islam Genggong, yang kemudian berubah lagi menjadi Pondok Pesantren Zainul Hasan dengan maksud untuk mengabadikan kedua pendiri pesantren tersebut yaitu K.H. Zainul Abidin dan K.H. Mohammad Hasan, tepatnya pada tanggal 1 Muharrom 1379 H/19 juli 1959 M. Nama Pesantren Zainul Hasan tersebut berlangsung sampai sekarang di bawah Kepemimpinan K.H. Hasan Mutawakkil Alallah.

Pesantren Zainul Hasan Genggong memiliki beberapa lembaga pendidikan yang dirintis saat kepemimpinan K.H Saifurridzal (1951-1991), yang berada di bawah naungan Kemenag dan Kemendikbud seperti MI Zainul Hasan, MTs. Zainul Hasan, TK Zainul Hasan, MA Zainul Hasan, SMA Zainul Hasan, SMK Zainul Hasan, SMP Zainul hasan, SD Zainul Hasan, dan Madrasah Diniyah. Bahkan untuk jenjang Perguruan Tingginya pun didirikan STAI Zainul Hasan, STIH, INZAH, AKPERAKBID dan STIKES Zainul Hasan.

Untuk merespons kebutuhan masyarakat yang menginginkan formalisasi lembaga pendidikan pesantren, dan dorongan yang kuat dari pemerintah, maka didirikanlah Pendidikan Diniyah Formal (PDF) Ulya tahun 2015. Pendidikan Diniyah Formal Ulya Zainul Hasan Genggong merupakan Pendidikan setara dengan SLTA/MA yang diakui ditingkat Nasional yang berada di bawah Naungan Pondok Pesantren Zainul Hasan Genggong. Penyelenggaraan PDF Ulya Zainul Hasan sepenuhnya mengacu pada PMA RI No 13 tahun 2014 tentang Pendidikan Keagamaan Islam dan Keputusan Direktur Jenderal Pendidikan Islam No. 5839 tahun 2014 tentang Pedoman Pendirian Pendidikan Diniyah Formal.

Kurikulum PDF Ulya Zainul Hasan mengembangkan nilai-nilai budaya dan karakter bangsa sebagai satu kesatuan yang terintegrasi pada setiap mata pelajaran. Nilainilai yang dikembangkan antara lain religius, jujur, toleransi, disiplin, kerja keras, kreatif, mandiri, demokratis, rasa ingin tahu, semangat kebangsaan, cinta tanah air, menghargai prestasi, komunikatif, cinta damai, gemar membaca, peduli sosial dan lingkungan, serta bertanggungjawab. Prinsip pengelolaan kurikulum ialah berpusat pada potensi, perkembangan kebutuhan, dan kepentingan peserta didik; beragam dan terpadu; tanggap terhadap ilmu pengetahuan dan teknologi; 
relevan dengan kebutuhan kehidupan; menyeluruh dan berkesinambungan; belajar sepanjang hayat dan seimbang antara kepentingan nasional dan kepentingan daerah.

PDF Ulya Zainul Hasan menekankan pengembangan kurikulum pada pendidikan kecakapan hidup (life-skill) yang diimplementasikan dalam pengembangan kegiatan ekstrakurikuler dan suatu kebijakan yang disebut santri khidmah dan musafir. Pendidikan kecakapan hidup (life-skill) adalah kecakapan yang dimilki oleh seorang santri PDF untuk berani menghadapi problema hidup dan kehidupan dengan wajar tanpa merasa ada tekanan, kemudian secara proaktif dan kreatif mencari serta menemukan solusi sehingga mampu mengatasi problema yang dihadapi dalam kehidupan nyata di masyarakat. Kecakapan hidup sangat dibutuhkan oleh santri karena tuntutan santri di zaman sekarang tidak hanya berkompeten dalam kitab kuning (mutafaqquh fiddin) tapi tuntutan penguasaan kompetensi yang lainpun sangar dibutuhkan. Bentuk life-skill yang dikembangkan PDF Ulya Zainul Hasan ialah teknik komputer, training pengurusan jenazah, koperasi, pencak silat, pagar nusa, marawis dan seni Hadrah.

Selain itu juga dikembangkan life-skills dalam beberapa kegiatan ekstrakurikuler antara lain kelompok bahsul masail, bimbingan bahasa arab, bimbingan khitobah, dan pelatihan manasik haji. Pembiasaan seperti pelaksanaan shalat berjamaah setiap lima waktu, upacara hari senin, dan membaca doa pembuka belajar setiap awal pelajaran merupakan kewajiban yang harus dipatuhi oleh setiap santri PDF. Untuk menjaga kualitas santri, pesantren menerapkan kebijakan seorang santri yang tidak lulus ujian (imtihan) otomatis mereka akan turun dengan sendirinya, bahkan ketika ada santri yang merasa tidak mampu dalam suatu pelajaran, maka dengan sukarela dan kesadaran sendiri mereka mengajukan permohonan untuk turun kelas, ke kelas yang lebih rendah.

Strategi yang lain dalam memperkuat pendidikan life-skills ialah kebijakan santri khidmah dan santri musafir. Kebijakan ini dilakukan PDF Ulya Zainul Hasan untuk meningkatkan kualitas santri. Santri khidmah adalah seorang santri diberikan ijazah atau santri dianggap lulus apabila sudah melakukan khidmah, yaitu santri lulusan PDF Ulya dikirim ke berbagai pondok pesantren alumni untuk mengabdi dan menularkan ilmu yang diperoleh di PDF, setelah dianggap cukup mereka kembali ke pondok pesantren dan mendapatkan ijazah dan dianggap lulus. Sedangkan santri musafir adalah santri khusus yang dikirim ke luar negeri untuk belajar di sana. Selama ini Negara-negara yang menjadi tujuan adalah Yaman, Mesir dan Libanon, dengan syarat mereka hafal kitab Zubad, sebuah kitab Nadham berisi kajian fiqih karangan Ibnu Ruslan. Sementara untuk meningkatkan kualitas intrakurikuler diadaklan penguatan pada kitab kuning, bimbingan baca Al-Qur'an bittartil dan bittaghanny, takhasus dalam ilmu alat dan fiqih, penguatan pada hifdun nadham, membiasakan kultum dan hafalan juz amma.

\section{Faktor Pendukung Keberhasilan Pengembangan Kurikulum PDF Ulya Zainul Hasan}

Keberhasilan pengembangan kurikulum PDF Ulya Zainul Hasan Genggong didukung oleh beberapa faktor antara lain konteks, input, proses dan output. Konteks kelahiran PDF Ulya Zainul Hasan adalah sebagai respon terhadap masyarakat yang menginginkan formaliasi lembaga pendidikan pesantren. Dari segi input, faktor yang paling berpengaruh adalah siswa dan guru. Pada Tahun Pelajaran 1439/1440 H (2018/2019), PDF Ulya Zainul Hasan melakukan rekrutmen santri dengan berbagai media diantarnya brosur, medsos (WA, facebook, twitter, instagram), sosialisasi ke wali santri, penyebaran kalender dan gerakan rekrutmen yang dilakukan oleh para alumni. Selain itu ada persyaratan khusus yang harus dimiliki setiap pendaftar yaitu bisa baca kitab kuning dan menguasai ilmu Nahwu dan Sharaf, dengan usia maksimum 20 tahun. Santri PDF Ulya Zainul Hasan kebanyakan berlatarbelakang pendidikan Diniyah Wustha Pendidikan Pondok Pesantren (PPS). Perkembangan santri digambarkan pada Tabel 1. 
Tabel 1. Perkembangan Santri/Peserta Didik PDF Ulya Zainul Hasan Genggong Tahun 2015-2018

\begin{tabular}{|c|c|c|c|c|c|}
\hline \multirow{2}{*}{ No. } & \multirow{2}{*}{ Kelas } & \multicolumn{4}{|c|}{ Tahun Ajaran } \\
\hline & & 2015 & 2016 & 2017 & 2018 \\
\hline 1 & $\mathrm{I}$ & 44 & 50 & 39 & 69 \\
\hline 2 & II & & 44 & 50 & 39 \\
\hline 3 & III & & & 43 (lulusan Pertama) & 50 (lulusan Ke dua) \\
\hline \multicolumn{2}{|c|}{ Jumlah } & 44 & 94 & 132 & 158 \\
\hline \multicolumn{2}{|c|}{ Rombel } & 2 & 4 & 6 & 6 \\
\hline \multicolumn{2}{|c|}{ Trend } & Naik & Naik & Naik & Naik \\
\hline
\end{tabular}

Peserta didik PDF Ulya Zainul Hasan setiap tahun mengalami peningkatan, dengan rincian tahun 2015 berjumlah 44, tahun 2016 sejumlah 94, dan tahun 2017 sejumlah 132. Pada tahun pelajaran 2018/2019 ini tercatat 158 santri yang terdaftar, dengan rincian kelas satu sejumlah 69, kelas dua berjumlah 39 dan kelas tiga berjumlah 50 peserta didik. Mereka belajar di PDF Ulya Zainul Hasan ini tidak dipungut biaya atau gratis untuk biaya sekolah, pakaian seragam, dan uang pendaftaran untuk siswa baru. Alasan santri melanjutkan ke PDF Ulya ini ialah ingin mendalami ilmu Agama Islam dan mempelajari kitab-kitab salaf (kitab kuning) dengan niat yang tulus semata-mata beribadah kepada Allah. Mereka beranggapan bahwa tradisi keilmuan di pesantren masih terjaga dengan baik. Bagi mereka, PDF merupakan madrasah yang istimewa yang mempelajari kitab-kitab keislaman dan mengakui pesantren sebagai lembaga pendidikan formal. Kebanyakan mereka berharap bahwa setelah selesai dari PDF Ulya ini bisa melanjutkan ke Ma'had Aly dan bisa mengabdikan ilmu yang dipelajari di masyarakat.

Sedangkan ustad atau pendidik PDF Ulya Zainul Hasan berjumlah 19 orang, yang terbagi pada mata pelajaran keagamaan, umum dan muatan lokal. Sistem rekrutmen pendidik dilakukan secara ketat. Beberapa persyaratan pendidik yang harus dipenuhi untuk pendidikan keagamaan antara lain berpendidikan S1, mampu membaca kitab kuning dan bahasa arab. Sedangkan untuk mata pelajaran umum harus berpendidikan S1 sesuai jurusan, serta IPK minimal 3. Pendidik PDF Ulya Zainul Hasan mayoritas sudah sesuai dengan kualifikasi yang dibutuhkan yaitu berpendidikan S1. Pendidik yang mengajar pada mata pelajaran pendidikan keagagamaan Islam mayoritas merupakan alumni dari Pondok Pesantren Genggong, sedangkan pendidik yang mengajar mata pelajaran umum merupakan lulusan dari Perguruan Tinggi Umum seperti Unesa dan UNM.

Untuk meningkatkan kualitas pendidik dan tenaga kependidikan, strategi yang dilakukan adalah menyelenggarakan diklat pengembangan tenaga pendidik dan kependidikan, diklat pengembangan kurikulum, pelatihan menyususn perangkat pembelajaran, pelatihan manajemen dan leadership, pelatihan Metode Al-Qur'an, pelatihan amtsilati, diklat pembuatan naskah soal UMBN, workshop layanan manajemen dan peningkatan mutu PDF. Disamping itu, untuk memperkuat jaringan dalam organisasi antar PDF, guru dan semua tenaga kependidikan terlibat dalam Asosiasi Pendidikan Diniyah Formal (ASPENDIF).

Perencanaan Pembelajaran di PDF Ulya Zainul Hasan Genggong Probolinggo dilakukan dengan analisis dokumen dan pengamatan terkait pengembangan silabus dan Rencana Pelaksanaan Pembelajaran (RPP) yang dilakukan oleh guru. Guru menyusun program mencakup program tahunan, semester, bulanan dan harian, dan kemudian menuangkannya dalam RPP. Pengembangan silabus dan RPP sudah sesuai dengan Kurikulum dan mengacu kepada standar isi yang ditetapkan pemerintah. Setiap ustad menyususn RPP berdasarkan kalender yang ditetapkan oleh sekolah dan yayasan.

Kegiatan formal PDF Ulya Zainul Hasan dimulai dari hari Sabtu sampai dengan kamis (07.15 sd 12.00). Proses pembelajaran mereka 
didukung dengan ektrakurikuler diantaranya pengajian kitab kuning, bimbingan baca AlQur'an bit-tartil dan bittaghanny dan bimbingan pencak silat. Kegiatan formal dan ekstra juga didukung oleh kegitan penunjang diantaranaya musyawaroh, bimbingan bahasa Arab, bimbingan khitobah, bimbingan Bahsul Masail, pembiasaan sholat berjamaah, pelatihan mengurus jenazah, Pelatihan Ibadah dan Pelatihan Manasik Haji.

Tabel 2. Proses Pendidikan di PDF Ulya Zainul Hasan

\begin{tabular}{|c|c|c|}
\hline Kegiatan Formal & Kegiatan Ekstra & Kegiatan Penunjang \\
\hline $\begin{array}{l}\text { Hari sabtu - kamis jam } \\
07.15-12.00 \text { (Belajar di } \\
\text { PDF) hari jum'at libur }\end{array}$ & $\begin{array}{ll}\text { 1. Pengajian Kitab Kuning } \\
\text { 2. Bimbingan Baca Al- } \\
\text { Qur'an Bittartil \& } \\
\text { Bittaghanny } \\
\text { 3. Bimbingan Pencak silat } \\
\text { (Pagar Nusa) } \\
\text { 4. Hadrah } \\
\text { 5. Marawis }\end{array}$ & $\begin{array}{ll}\text { 1. } & \text { Musyawaroh Bimbingan } \\
\text { Bhs. Arab } \\
\text { 2. } \\
\text { 3. Bimbingan Khitobah } \\
\text { 4. Pembiasaan Sholat Jama'ah } \\
\text { 5. Pelatihan Mengurus Jenazah } \\
\text { 6. Pelatihan Ibadah } \\
\text { 7. Pelatihan Manasik Haji }\end{array}$ \\
\hline
\end{tabular}

Setelah selesai di PDF Ulya, santri melanjutkan kegitan proses pembelajran di pesantren baik harian, mimgguan, bulanan dan tahunan. Kegitan harian mereka digambarkan sebagai berikut .

Tabel 3. Kegitan Harian Santri Zainul Hasan

\begin{tabular}{ccl}
\hline No & \multicolumn{1}{c}{ Jam } & \multicolumn{1}{c}{ Kegiatan } \\
\hline 1. & $03.00-04.00$ & Tahajjud \\
\hline 2. & $04.00-05.00$ & Sholat Shubuh \& Wiridan \\
\hline 3. & $05.00-06.00$ & Pengajian Kitab Salafiyah \\
\hline 4. & $06.00-06.30$ & Ke Maqbaroh lanjut Sholat Dhuha \\
\hline 5. & $06.30-07.00$ & Persiapan Sekolah \\
\hline 6. & $07.00-13.00$ & Kegiatan Sekolah Formal \\
\hline 7. & $13.00-14.00$ & Sholat Dhuhur \\
\hline 8. & $14.00-15.00$ & Kegiatan Sekolah Formal (Sekolah Fullday) \\
\hline 9. & $14.00-15.00$ & Istirahat (Sekolah non Fullday) \\
\hline 10. & $15.00-16.00$ & Kegaiatan ekstrakurikuler pada masing2 sekolah \\
\hline 11. & $16.30-18.00$ & Pengajian Kitab Salafiyah \\
\hline 12. & $18.00-18.30$ & Sholat Maghrib \\
\hline 13. & $18.30-19.00$ & Bimbingan mengaji Al-Qur'an \\
\hline 14. & $19.00-20.00$ & Sholat Isyak \& Wiridan \\
\hline 15. & $20.00-21.00$ & $\begin{array}{l}\text { Belajar mandiri dan didampingi oleh guru kelas } \\
\text { atau bagi yang bersekolah di lembaga non- } \\
\end{array}$ \\
& & $\begin{array}{l}\text { madrasah (SMP \& SMA) dilanjutkan dengan } \\
\text { Madrasah Diniyah }\end{array}$ \\
\hline 16. & $21.00-22.00$ & Bimbingan belajar kitab salafiyah \\
\hline 17. & $22.00-03.00$ & Kegiatan mandiri dan istirahat \\
\hline
\end{tabular}

Selain kegitan tersebut, pada setiap jumat di minggu ke-dua, setiap santri seluruh pesantren mengikutui kegiatan olahraga bersama yaitu bersepeda dan jogging bersama seluruh pengasuh yayasan dan ustad Pesantren Zainul Hasan Genggong. Biasanya berkeliling kampung dan jalan di wilayah Kabupaten Probolinggo dengan rute yang berbeda-beda.

PDF Ulya Zainul Hasan sejak berdiri tahun 2015 sampai tahun 2019 ini sudah menjalankan Ujian Nasional (Imtihan Wathani) sebanyak dua kali. Imtihan Wathani tahun 2018 dan 2019 berjalan sesuai program 
walaupun menggunakan biaya mandiri baik untuk soal, kepanitiaan, pengawasan dan monitoring. Rata-rata nilai mata pelajaran akhir semester PDF Ulya Zainul Hasan melampaui target KKM yang ditetapkan.
Analisis skor hasil Ujian Nasional (Imtihan Wathani) sudah memenuhi target yang ingin dicapai dengan tingkat kelulusan 100\%. Selain itu, beberapa santri berprestasi dalam bidang akademik diantaranya :

Tabel 4. Prestasi Akademik Santri PDF Ulya Zainul Hasan

\begin{tabular}{cll}
\hline No & \multicolumn{1}{c}{ Nama Santri } & \multicolumn{1}{c}{ Jenis Prestasi } \\
\hline 1 & Abdul Jalil & Hafal 1000 Bait Alfiyah \\
\hline 2 & Ali Ridho & Hafal 700 Bait Alfiyah \\
\hline 3 & Karimulloh Musleh & Hafal 1000 Bait Alfiyah \\
\hline 4 & 20 Santri & Menulis Mushaf Tingkat Nasional \\
\hline 5 & 7 Santri & $\begin{array}{l}\text { Lomba Baca Kitab dan Hifdlun Nadhom } \\
\text { Tingkat Provinsi Jawa Timur }\end{array}$ \\
\hline
\end{tabular}

Prestasi non-akademik santri PDF Pesantren Zainul Hasan Genggong sangat mengagumkan. Indikator tersebut bisa dilihat dari pelaksanaan ibadah sehari-hari, sikap disiplin, dan akhlakul karimah. Di PDF Ulya Zainul Hasan Genggong terdapat upaya pembiasaan dalam pelaksanaan ibadah shalat lima waktu, setiap santri wajib berjamaah setiap waktu. Besarnya semangat santri dalam melaksanakan kegiatan ibadah, tingkat kedisiplinan yang tinggi dalam kehadiran, pergaulan, maupun dalam belajar. Tidak terdapat kasus-kasus kenakalan remaja, seperti perkelahian berat, dan narkoba, karena pesantren mengajarkan doktrin agama yang sangat kuat pada santri, ditambah dengan pengawasan yang ketat. Prestasi non-akademik yang lain ialah kemahiran santri dalam berbagai kegiatan ekstra seperti pagar nusa, hadrah dan marawis.

Dengan penguasaan kitab kuning yang mumpuni, santri PDF Ulya Zainul Hasan diharapkan menjadi seorang yang bebar-benar mutafaqquh fiddiin, yang didambakan masyarakat karena bisa menjawab kebutuhan dan tantangan masyarakat dalam menyelesaikan permasalahan-permasalahan sosial dan keagamaan. Santri berperan dalam membentuk karakter bangsa, memberikan contoh dengan berakhlakul karimah, hidup bermartabat dan beradab serta berperan menjadi benteng moral dalam menghadapi derasnya globalisasi dan sekularisme yang melanda bangsa ini.

Alumni PDF Ulya Zainul Hasan Genggong banyak terlibat aktif dalam penyebaran ilmu keagamaan di masyarakat terutama mereka mengabdi di pesantrenpesantren para alumni. PDF Ulya Zainul Hasan sampai tahun 2019 tercatat telah meluluskan 93 alumni, yakni tahun 2017 sebanyak 43 orang dan tahun 2018 sebanyak 50 orang. Bahkan ada diantara mereka yang melanjutkan studi ke luar negeri diantaranya Yaman, Mesir dan Libanon. Salah seorang alumni yang baru pulang dari Yaman tahun ini ialah Saiful Anwar, ia merupakan lulusan Rubatiarim Yaman, yang fokus mendalami Ilmu Fiqih dan Nahwu. Sekarang ia menjadi pengajar dan mengabdi di PDF Ulya Zainul Hasan. Untuk Alumni tahun 2018 dan 2019 ini kebanyakan mereka akan melanjutkan di Mahad Aly yang akan segera di buka untuk angkatan pertama tahun 2019/2020 dengan jumlah pendaftar 60 santri.

PDF Ulya Zainul Hasan didukung berbagai kelengkapan yang memadai seperti sarana dan prasarana, dukungan masyarakat, kurikulum yang terstandar dan lingkungan yang kondusif dan strategis. Kendala PDF Ulya ini yaitu masih baru, belum banyak dikenal masyarakat, lebih banyak membutuhkan kepercayaan dari masyarakat, kurangnya fasilitas dari pemerintah terkait media pembelajaran dan kemampuan santri baru yang sesuai standar PDF.

\section{Integrasi Konsep Mutafaqquh Fiddin Dengan Pendidikan Life Skills Pada PDF Ulya Zainul Hasan}

Dalam mengembangkan sebuah kurikulum ada lima prinsip yang harus menjadi 
pedoman bagi seorang pengembang kurikulum yaitu prinsip relevansi, fleksibilitas, kontinuitas, efektivitas dan efisiensi (Sanjaya, 2010,39-42). Apa yang dilakukan PDF Ulya Zainul Hasan dengan menekankan pengembangan kurikulumnya pada kecakapan hidup (life-skill), pengembangan pada kegiatan ekstrakurikuler dan kebijakan santri khidmah dan musafir merupakan upaya dalam rangka memenuhi lima prinsip pengembangan kurikulum. Pertama, prinsip relevansi, artinya bahwa yang dilakukan sudah relevan baik secara internal maupun eksternal. Relevan secara internal karena terdapat keserasian antara komponen-komponennya dan tujuan yang ingin dicapai. Relevan secara eksternal berkaitan dengan lingkungan hidup peserta didik, relevan dengan perkembangan zaman dan tuntutan dunia pekerjaan saat ini, di mana seorang santri tidak hanya ahli dalam kitab kuning tapi dibekali dengan kompetensi yang lain.

Kedua, prinsip fleksibilitas, bahwa kurikulum harus bisa dilaksanakan sesuai dengan kondisi yang ada. PDF Ulya Zainul Hasan menyadari bahwa kurikulum yang kaku atau tidak fleksibel akan sulit dilaksanakan. Kurikulum harus memberikan ruang bagi guru untuk mengembangkan program pengajarannya sesuai dengan kondisi yang ada. Kurikulum juga menyediakan ruang bagi siswa untuk melakukan pilihan sesuai dengan bakat dan minat yang dimilikinya. Ketiga, prinsip kontinuitas. Prinsip ini mengandung pengertian bahwa perlu dijaga saling keterkaitan dan kesinambungan antara materi pelajaran pada berbagai jenjang PDF. Keempat, prinsip efektivitas berkenaan dengan rencana dalam suatu kurikulum dapat dilaksanakan dan dapat dicapai dalam kegiatan belajar mengajar di PDF baik oleh guru maupun santri. Kelima, prinsip efisien berkaitan dengan perbandingan antara tenaga, waktu, dan biaya yang dikeluarkan dengan hasil yang diperoleh. PDF berpandangan bahwa kurikulum memiliki tingkat efisiensi yang tinggi apabila dengan sarana, biaya minimal dan waktu yang terbatas dapat memperoleh hasil yang maksimal.

Data memperlihatkan bahwa PDF Ulya Zainul Hasan berhasil mengintegrasikan konsep Mutafaqquh Fiddiin dengan pendidikan life skills. Keberhasilan tersebut didukung beberapa faktor di antaranya konteks pesantren dan masyarakat, input santri dan ustadz, proses pembelajaran dan out-put lulusan yang berkualitas. Namun keberhasilan ini belum didukung regulasi pemerintah yang mendorong bagaimana agar PDF tersosialisasi dengan baik di masyarakat, karena faktanya memang PDF belum dikenal secara luas di masyarakat, termasuk di dalam instansi Kementerian Agama sendiri belum sepenuhnya mengenal dan mengetahui apa dan bagaimana Pendidikan Diniyah Formal itu. Hal ini sebagai akibat dari sistem pengelolaan PDF yang memang dikelola secara sentralistik oleh Kementerian Agama pusat dalam hal ini adalah Direktorat Diniyah dan Pondok Pesantren.

Pada tingkat lokal Kabupaten Probolinggo, di mana penelitian ini dilakukan, Kantor Kementerian Agama Kabupaten tidak dapat mengurus secara penuh dalam penyelenggaraan PDF karena kewenangannya secara sentralistik berada di bawah pemerintah pusat dalam hal ini adalah Direktorat Pendidikan Diniyah Pondok Pesantren. Kasi Pendidikan Diniyah dan Pondok Pesantren kadang tidak mengetahui kebijakan di tingkat pusat karena biasanya sosialisasi langsung diadakan ke-PDF yang bersangkutan. Kantor Kementerian Agama kabupaten hanya sebagai Pembina dan pendamping saja khususnya dalam izin pendirian, selebihnya kebijakan menjadi kewenangan pemerintah pusat seperti dalam hal penyelenggaraan Ujian Nasional (imtihan wathani), distribusi dan pembuatan soal, kepanitiaan, pengawasan dan administrasi lainnya sudah ditangani pemerintah pusat.

PDF Ulya Zainul Hasan belum mendapatkan hak-hak yang sama seperti lembaga pendidikan formal lainnya yang berada di bawah naungan Kementerian Agama dan Kementerian Pendidikan dan Kebudayaan, seperti pembiayaan, pemberian bantuan, akreditasi, sertifikasi dan fasilitas lainnya. Pada sisi yang lain PDF Ulya Zainul Hasan Genggong belum terakreditasi, padahal PMA No 13 Tahun 2014 tentang Pendidikan Keagamaan Islam paragraf 11 pasal 44 ayat 1 dan 2 mensyaratkan bahwa setiap lembaga PDF wajib mengikuti proses akreditasi. 
Dalam pelaksanaan Ujian Nasional (imtihan wathani), PDF belum mendapatkan anggaran yang sama seperti sekolah atau madrasah formal lain baik yang berada di bawah naungan Kementerian Agama ataupun Kementerian Pendidikan. PDF harus membayar sendiri untuk kepentingan soal, pengawasan, kepanitiaan dan administrasi lainnya. Sementara sekolah atau madrasah formal mendapatkan pembiayaan khusus dari pemerintah untuk Ujian Nasional, ujian semester, ataupun ujian madrasah. Ketika penelitian ini dilakukan, PDF Ulya Zainul Hasan secara kelembagaan belum terakreditasi sebagaimana tuntutan dari PMA No 13 Tahun 2014 tentang Pendidikan Keagamaan Islam paragraf 11 pasal 44 ayat 1 dan 2 . Padahal akreditasi merupakan strategi penjaminan dan pengendalian mutu pendidikan. Akreditasi merupakan strategi untuk menilai kelayakan suatu lembaga dalam menyelenggarakan pendidikan.

Pada aspek guru atau ustaz, ketika diadakan penelitian ini, ternyata ustaz PDF belum mendapatkan hak-hak yang sama sebagaimana guru pada lembaga pendidikan formal lainnya, mereka belum mendapatkan tunjangan fungsional, tunjangan profesi (sertifikasi) atau hak mendapatkan inpassing. Sertifikasi misalnya, dimaksudkan untuk menjamin kelayakan tenaga pendidik yang memiliki kualifikasi dan kompetensi yang cukup sehingga dapat dinyatakan sebagai pendidik profesional. Padahal ini penting dan menjadi hak guru sebagai tuntutan dari PMA No. 13 Tahun 2014 tentang Pendidikan Keagamaan Islam, dan juga Undang-undang Guru dan Dosen No 14 tahun 2005.

PDF Ulya Zainul Hasan merupakan satuan pendidikan yang memberikan warna dan kekuatan tersendiri bagi pesantren karena bisa menjadi jembatan bagi masyarakat yang menginginkan anaknya untuk mengkhususkan mempelajari ilmu agama khususnya dalam kitab kuning. Namun yang menjadi tantangan PDF ke depan adalah adanya persaingan dengan lembaga-lembaga pendidikan lain dalam menciptakan qulity assurance, bagaimana PDF menjamin bahwa lulusannya memang ahli dalam bidang ilmu agama (mutafaqquh fiddin) yang siap berkontribusi di masyarakat. Menjalankan fungsi mutafaqquh fiddin semakin berat karena ada kecenderungan semakin minimnya peserta didik yang menimba ilmu agama karena faktor globalisasi yang sebagian masyarakat lebih memilih pendidikan umum sebagai alternatif dalam menghadapi dunia kerja.

Koordinasi dan kerjasama yang dilakukan PDF dengan berbagai unsur baik kemenag, kemendikbud maupun pengurus yayasan, untuk meningkatkan inovasi dalam berbagai aspek, serta memberikan motivasi dan pemahaman kepada santri tentang pentingnya generasi yang menguasai ilmu agama merupakan langkah yang tepat untuk memastikan eksistensi lembaga PDF dalam berkontribusi dimasa yang akan datang. Integrasi konsep mutafaqquh fiddiin dengan pendidikan kecakapan hidup yang dikembangkan PDF Ulya Zainul Hasan merupakan strategi yang tepat dalam rangka menjawab tantangan zaman dan memberikan jawaban kepada masyarakat bahwa out-put PDF bisa berkontribusi dan memiliki prospek masa depan yang lebih baik.

\section{PENUTUP}

Ternyata apa yang selama ini dibayangkan bahwa Pendidikan Diniyah Formal (PDF) hanya berurusan dengan kitab kuning terbantahkan, fakta lapangan memperlihatkan bahwa PDF Ulya Zainul Hasan Genggong mampu mengembangkan kurikulumnya pada pendidikan kecakapan hidup. Santri dibekali dengan berbagai keterampilan seperti teknik komputer, koperasi, pencak silat/Pagar Nusa, marawis dan seni Hadrah. Selain itu juga dikembangkan beberapa kegiatan ekstrakurikuler antara lain Kelompok Bahsul Masail, bimbingan bahasa arab, bimbingan khitobah, dan pelatihan manasik haji. Keberhasilan pengembangan kurikulum PDF ini didukung oleh berbagai hal seperti kebijakan pesantren yang menerapkan santri khidmah dan musafir, input santri dan ustadz, proses pembelajaran dan output lulusan yang bisa berkontribusi dalam memberikan warna di masyarakat.

Hal itu sejalan dengan teori yang dikembangkan para ahli kurikulum tentang lima prinsip pengembangan kurikulum yaitu 
prinsip relevansi, fleksibilitas, kontinuitas, efektivitas dan efisiensi. Kurikulum PDF Ulya Zainul Hasan relevan dengan perkembangan zaman dan tuntutan dunia pekerjaan saat ini, bisa dilaksanakan sesuai dengan kondisi yang ada, saling keterkaitan dan berkesinambungan, dapat dilaksanakan dan memiliki tingkat efisiensi yang tinggi dengan hasil yang maksimal.

Penelitian ini merekomendasikan pertama, pengembangan kurikulum dengan penekanan life skills di PDF perlu dikembangkan dalam rangka menjawab kebutuhan pasar dan tuntutan masyarakat akan dunia kerja. Lulusan PDF diharapkan bukan hanya mahir dalam penguasaan kitab kuning, tapi juga memiliki kompetensi dan keterampilan tertentu.

Kedua, Pendidikan Diniyah Formal (PDF) merupakan jenis pendidikan yang masih baru, dan dianggap asing oleh sebagian masyarakat, oleh karena itu Kementerian Agama melalui Direktorat Jenderal Pendidikan Islam, khususnya Direktorat Pendidikan Madrasah dan Pondok Pesantren perlu menyusun core yang lebih jelas tentang arah, tujuan dan orientasi Pendidikan Diniyah Formal (PDF), serta mensosialisasikannya secara masif melalui jalur Kementerian Agama, Kementerian Pendidikan, pondok pesantren, dan masyarakat umum, sehingga tercipta Brand Image yang positif tentang Pendidikan Diniyah Formal.

Ketiga, Kementerian Agama melalui Direktorat Jenderal Pendidikan Islam, khususnya Direktorat Pendidikan Madrasah dan Pondok Pesantren perlu mengupayakan agar anggaran dan pembiayaan PDF seperti Ujian Nasional (Imtihan Wathani) atau anggaran lainnya memiliki porsi yang sama seperti sekolah atau madrasah formal lainnya yang berada di bawah Kementerian Pendidikan dan Kebudayaan dan Kementerian Agama. Ketiga, Sebagai implementasi dari PMA No 13 Tahun 2014 Tentang Pendidikan Keagamaan Islam paragraf 11 pasal 44 ayat 1 dan 2, Kementerian Agama melalui Direktorat Jenderal Pendidikan Islam, khususnya Direktorat Pendidikan Madrasah dan Pondok Pesantren perlu segera melakukan Akreditasi pada seluruh lembaga PDF, dan menyelenggarakan Sertifikasi guru bagi para pendidik dan ustadz PDF.

\section{UCAPAN TERIMAKASIH}

Peneliti mengucapkan terima kasih kepada Kepala Puslitbang Pendidikan Agama dan Keagamaan Badan Litbang dan Diklat Kementerian Agama RI yang telah memberikan kesempatan untuk melakukan penelitian ini. Terima kasih juga kepada rekanrekan peneliti Puslitbang Penda khususnya bidang Pendidikan Keagamaan yang sudah memberikan masukan dan meluangkan waktu untuk berdiskusi terkait hasil penelitian ini. Ucapan terima kasih juga penulis sampaikan kepada keluarga besar Pondok Pesantren Zainul Hasan Genggong Probolinggo Jawa Timur, khususnya PDF Ulya Zainul Hasan yang dengan senang hati menerima peneliti dan memberikan data dan informasi terkait penelitian ini.

\section{DAFTAR PUSTAKA}

Bahri, Samsul.(2018). Pengembangan Kurikulum Berbasis Multikulturalisme Di Indonesia (Landasan Filosofis Dan Psikologis Pengembangan Kurikulum Berbasis Multikulturalisme), Jurnal Ilmiah Didaktika Vol. 19, NO. 1, Agustus 2018 VOL. 19, NO. 1, 69-88.

Busthomi, Yazidul.(2019). Pengembangan dan Evaluasi Kurikulum Pendidikan Di Pondok Pesantren Desa Ganjaran Gondanglegi Malang. Jurnal Pendidikan Islam An-Naba. Volume 5 No. 2, 1 September 2019, 217-234.

Dewi, R., \& Limbong, J. (2018). Manajemen Pendidikan Diniah Formal, , 23-29. Madrasa: Journal of Islamic Educational Management VOL.1, 2018, 023-029.

Dokumen Kurikulum Pendidikan Diniyah Formal (PDF) Ulya Zainul Hasan Genggong Probolinggo Jawa Timur, Tahun Pelajaran 1439/1440 H (2018/2019).

Dudin, Achmad. (2019). Evaluasi Penyelenggaraan Pendidikan Diniyah Formal (PDF) Pesantren 
Darussalamciamis Jawa Barat, Journal Dialog Vol. 42, No.2, Des 2019.

Genggong.

(2018).Https://www.pzhgenggong.or.id/ latar-belakang (Diakses Rabu, 27 Maret 2019, jam 20.25.

Hamalik, Oemar. (2010). Manajemen Pengembangan Kurikulum. Bandung : Remaja Rosdakarya.

Hasan, Hamid. (2009). Evaluasi Kurikulum. Bandung : Remaja Rosdakarya.

Hidayat, Ahmad Wahyu. (2020). Studi Kebijakan Pengembangan Kurikulum Pendidikan Agama Islam Model Kurikulum 2013. Al-Murabbi, Jurnal Studi Kependidikan dan Keislaman, Vol. 6 No.2 (2020) : Januari 2020.

Indonesia.(2005).Undang-undang Guru dan Dosen No 14 tahun 2005. Indonesia.

Istiyani, Dwi.(2017). Tantangan dan Eksistensi Madrasah Diniyah sebagai Entitas Kelembagaan Pendidikan Keagamaan Islam di Indonesia. Edukasia Islamika Jurnal Pendidikan Islam Vol. 2 No. 1, Juni 2017, hlm. 127-145 P-ISSN: 2548723X; E-ISSN: 2548-5822

Kemenag. (2014).Keputusan Direktur Jenderal Pendidikan Islam No. 5839 tahun 2014 tentang Pedoman Pendirian Pendidikan Diniyah Formal. Indonesia

Kemenag. (2014). PMA No 13 Tahun 2014 Tentang Pendidikan Keagamaan Islam. Indonesia.

Mualim, R., Anshori, A., \& Ali, M. (2019). Implementasi Kurikulum 2013 Mata Pelajaran Pendidikan Agama Islam di SMP Negeri 1 Wonogiri dan SMP Negeri 1 Surakarta Tahun 2019, Profetika Jurnal Studi Islam, Vol. 20, No. 2, Desember 2019: 196-204.

Oliva, Peter F. \& Gordon, William II. 2012. Developing The Curriculum, $8^{\text {th }}$ Edition. New Jersey: Pearson Education, Inc.

Sahri, K. Ikhsan dan Hidayah, Lailatul. (2020). Kesetaraan Gender di Pesantren NU: Sebuah Telaah atas single sex
Classroom di Pendidikan Diniyah Formal Ulya Pondok Pesantren Al Fithrah Surabaya. JNUS: Journal of Nahdlatul Ulama Studies, Vol. 1, No. 1, Januari 2020: 67-105.

Salim, Agus.(2019). Kurikulum Dalam Perspektif Filsafat Pendidikan Islam. Jurnal EduTech Vol. 5 No. 2 September 2019

Sanjaya, Wina. (2008). Perencanaan dan Desain Sistem Pembelajaran. Jakarta: Kencana.

Sanjaya, Wina. 2010. Kurikulum dan Pembelajaran. Jakarta : Prenada Media Group.

Suroso. (2017). Manajemen Pembelajaran Pendidikan Diniyah Formal (PDF) Tingkat Wustho Pondok Pesantren Assalafi Al Fitrah Surabaya Suroso. Adabiyah Jurnal Pendidikan Islam, Volume 2 Nomor 2, Desember 201773 106, https://doi.org/10.21070/ja.v2i1.1237

Suyanto. (2016). Manajemen penjenjangan pendidikan diniyah formal pada pesantren di kota bengkulu, 69-77. An-Nizom Journal | Vol. I, No. 2, Agustus 2016.

Syamsudin. (2018). Mengembangkan Kemandirian Belajar Siswa Pendidikan Diniyah Formal (PDF) Wustha Al Fithrah Surabaya Menggunakan Model Pembelajaran Berdasarkan Masalah. Jurnal Tarbawi.Vol. 7 No.1, September 2018 , doi: https://doi.org/10.36781/tarbawi.v7i1.2 974

Syukron, $\quad$ Ahmad. (2020). Kurikulum Pendidikan Diniyah Formal Dalam Pondok Pesantren. Masters Thesis, Universitas Negeri Semarang.

Taufik, Ahmad. (2019). Pengembangan Kurikulum Pendidikan Islam. Journal el-Ghiroh. Vol. XVII, No. 02. September2019

Wahid, Abd. (2016). Pendidikan Diniyah Formal Wajah Baru Pendidikan Pesantren Untuk Kaderisasi Ulama. Syaikhuna Jurnal Pendidikan dan 
Pranata Islam Volume 7 Nomor 2 Oktober 2016.

Wibisono, Yogi. (2019). Pengembangan Dan Implementasi Kurikulum Ismuba Di Smp Muhmammadiyah Pakem Sleman Yogyakarata, Journal At-Tajdid: Vol. 03 No. 02 Juli-Desember 2019, 167179.
Wibowo, A.M.dkk.(2018). Kaderisasi Ulama Toleran melalui Pendidikan Diniyah Formal pada Pesantren Salafiyah di Jawa Tengah dan Jawa Timur. Semarang : Kementerian Agama RI, Balai Litbang Agama Semarang. 